\title{
University as the Core of the Functional Planning Organization of an Innovative City
}

\author{
Alla Pleshkanovska \\ Kyiv National University of Construction and Architecture \\ Povitroflotsky Prosp., 31, Kyiv, Ukraine, 03680 \\ pleshkanovska.am@knuba.edu.ua, orcid.org/0000-0001-9370-3570
}

Received 19.04.2020, accepted after revision 02.06.2020

https://doi.org/10.32347/uwt2020.10.1902

\begin{abstract}
The rapid spread of IT technologies at the current stage of human new economic development, the formation of smart and innovative cities demonstrates extraordinary growth of the science and education significance. As a result, universities, research centres and high-tech industries are more and more often beginning to be the core of the contemporary city spatial organization.

The article deals with the stages of universities historical development as society scientific thought and technological knowledge concentration - ancient (formation and development of philosophical thought), medieval (creation of universities and formation of scientific branches - the humanities or trivium development, and the exact sciences or quadrivium), modern (spread of exact sciences as a basis for technical and technological innovations and industrial production development).
\end{abstract}

Above mentioned universities' spatial development models are being characterized as an integral part of the city functional-planning organization, the predominant function of which is the educational or scientific-technological function. They are - monocentric (the university is the dominant integral planning element in the structure of the city); polycentric (formation of a group of universities as independent planning entities on the ground of a single historically formed university) and dispersed (spatial development of a mono- or polycentric model with the creation of separately located structural elements of the university, mainly in the peripheral city zone).

The actual quantitative indicators of the most typical foreign and domestic university cities, in particular, the share of teachers and students number in the total University City population are giv en below. The functions of the university at the

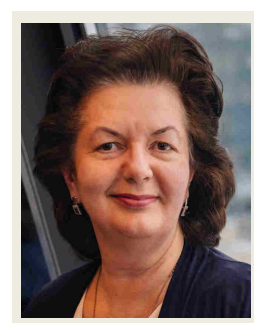

Alla Pleshkanovska

Professor of Land Management and Cadastre Department, KNUCA

Dr.Tech.Sc., Prof.

contemporary stage of the development of society are described - they are educational, research, educative, commercial and communicative ones.

The article presents the tendencies in the formation of the modern city functional planning organization. The examples of innovative cities spatial organization are - the city of Masdar (UAE) and UNIT-City (Ukraine). Recommendations on the eventual transformation of existing domestic cities according to the innovative University City model are given below.

Keywords: university, University City, innovative city, spatial functional planning organization; university functions.

\section{INTRODUCTION}

The end of the $20^{\text {th }}-$ beginning of the $21^{\text {st }}$ century is marked by the human entry into a new civilizational development stage, which was called neo-economy (new economy). A.L. Gregorian defines the "new economy" as the first stage of a new "post-industrial" system $[1,2]$. The new technological round has created a modern idea of the comprehensive development of free areas and reconstruction of 
existing areas as a new smart or innovative urban space type [3].

The growing significance of science and technology for the development of society during the fourth scientific and technological revolution requires the formation of a modern type of a person with well-grown potential, able to implement and maintain highly intelligent contemporary technologies [4]. But the new type person requires a new innovation space, which must meet the challenges of time $[5,6]$.

City as a spatial form of concentration of people, material infrastructure and technology at each historical stage of human development consolidates the idea of the human environment, development and self-identification [4, 7]. The post-industrial period created the latest forms of urban space, such as: ecopolises and arcopolises [7], hydropolises (underwater cities) [8], smart cities [3], vertical cities etc. But even well-known cities have undergone significant changes over the centuries under the influence of innovative ideas about the latest urban environment. Such cities, first of all, include university cities, the importance of which in the period of initial formation (The Middle Ages) and in the contemporary postindustrial stage is extremely important $[9,10]$.

Innovative university cities require a radical change in the usual city functional and planning organization spatial model. To meet the challenges of society, the formation of a highly educated modern person, it is the university with its research centers and experimental laboratories network that acquires a new meaningful existence and becomes the core of the spatial organization of the innovative city. The creation of new innovative university cities and the reconstruction of existing ones is becoming a priority.

Unfortunately, the national regulatory framework for urban planning does not meet such requirements. According to article 4.10 DBN B.2.2-12:2019 "Creation of new settlements can be provided in connection with the need to locate new large industrial enterprises, need of mineral resources production, as well as due to population resettlement from existing or potential zones of catastrophes and envi- ronmental disasters, historical and cultural factors" [11]. Awareness of the need to revise the main tasks of national urban planning should ensure the creation of preconditions for the formation of the modern world man.

\section{AIM AND RESEARCH METHODS}

The purpose of the study is to identify transformation patterns of the contemporary city functional planning organization, the core of which is the university as the basis of innovative development of society.

Based on the historical comparative research method, the transformation tendencies of the university spatial organization as an urban environment formation structural core are revealed. The graph-analytical method application allowed establishing the transformation regularities of the industrial city functional planning organization into a postindustrial innovative university city.

\section{RESULTS AND EXPLANATIONS}

University (from the Latin universitas - "a whole", universitas magistrorum et scholarium - community, association of teachers and scholars [12]) - an autonomous higher education institution type, which was formed in $\mathrm{Eu}-$ rope during The Middle Ages. Let's focus on some aspects of the formation and development of universities and university cities.

\section{1) Formation of the university as a basis for the city development.}

There are three basic periods of growing of knowledge and science significance for society as a whole and for person in particular.

The first period - ancient (Ancient Greece, Ancient Rome) - covers the period of the $6^{\text {th }}$ century $-2^{\text {nd }}$ century B.C., it includes several stages marked by the world-famous scientific schools formation [13]:

- Ionian stage. The Greek science origin period (natural philosophers - Thales of Miletus, Pythagoras, Heraclitus of Ephesus, Anaximander, Hippodamus of Miletus, etc.);

- Athenian stage. Covers 5-4 centuries 
B.C. and associated with the names of Aristotle, Socrates, Plato, Hippocrates of Chios;

- Alexandrian (Hellenistic) stage of ancient science development - 3-2 centuries B.C. Its representatives are Apollonius of Perga, Archimedes, and Aristarchus of Samos.

The ancient period science is characterized by the extraordinary role of the individual, surrounded by students and followers, who formed scientific schools. But such schools were based on a philosophical understanding of a surrounding world and the laws of its development; in fact, they did not require the developed infrastructure formation [13].

The next stage - the medieval - 12-16 centuries - is characterized by the antiquity cultural heritage revival (Renaissance). The growing desire in the cities to get education leads to the first educational institutions emergence episcopal, monastic, parish and cathedral schools. Monasteries played the role of education and science knowledge centers, as they accumulated numerous manuscripts, which mostly were copied by monks $[14,15]$.

The division of all "seven liberal arts" knowledge branches into two parts is introduced in training: trivium (three ways of knowledge - grammar, rhetoric and dialectics); quadrivium (four ways of knowledge geometry, arithmetic, astronomy and music) [14].

It is on the basis of monasteries and churches that universities are gradually starting to establish. The first universities appeared in the $12^{\text {th }}$ century in Bologna (Italy) and in Paris (France). Later on, they also appeared in other countries: Oxford, Cambridge - in England, Salamanca - in Spain, Prague - in the Czech Republic, Krakow - in Poland and more. At the end of the $15^{\text {th }}$ century there were 79 universities in Europe.

The Medieval University is no longer just a group of pupils, students, gathered around the spiritual and scientific leader of antiquity. The university must have the minimal necessary infrastructure to perform educational function - church, library, mess hall and gardens [16]. The lack of any component did not give the right to be called "university" or "college". It remained just a "school".
Gradually, the university, using modern terminology, begins to play the city forming role, implementing three basic functions: work or employment places concentration - the library, the church; everyday life - mess hall, cells; recreation - monastic and then university gardens.

The third stage - modern - conditioned the spread of scientific and technological progress in industry and production (the so-called STR - scientific and technological revolution). Even the names of the most famous universities, founded during this period, proved the unity of science and technology - Lviv Polytechnic National University (1816), Harvard University (1836), Massachusetts Institute of Technology (1861), I. Sikorsky Kyiv Polytechnic Institute "Kyiv Polytechnic" (1898), Imperial College, London (1907), Max Planck Institutes (1914), this list includes 83 universities and institutes of chemical-physicaltechnological and biological-medical orientation.

The science and technology development contributed to the formation and development of production and industry, capitalist relations formation and led to evolving numerous industrial type urban settlements. The university material and technical infrastructure is significantly developing, supplemented by research centres, experimental laboratories and even research facilities [17].

\section{2) University as a component of the city spatial organization}

The University City at the initial stage of its evolving performed mainly the concentration of scientific thought and dissemination of educational knowledge functions. City territory functional and planning organization represented a concentrated placement of all university functional components within the monastery walls, which, as a rule, played the role of city borders, protecting it from possible invasions. The medieval University City population consisted mainly of students and teachers. For example, in the $12^{\text {th }}$ century in the "happy city" of Paris the students outnumbered the local population [18]. 


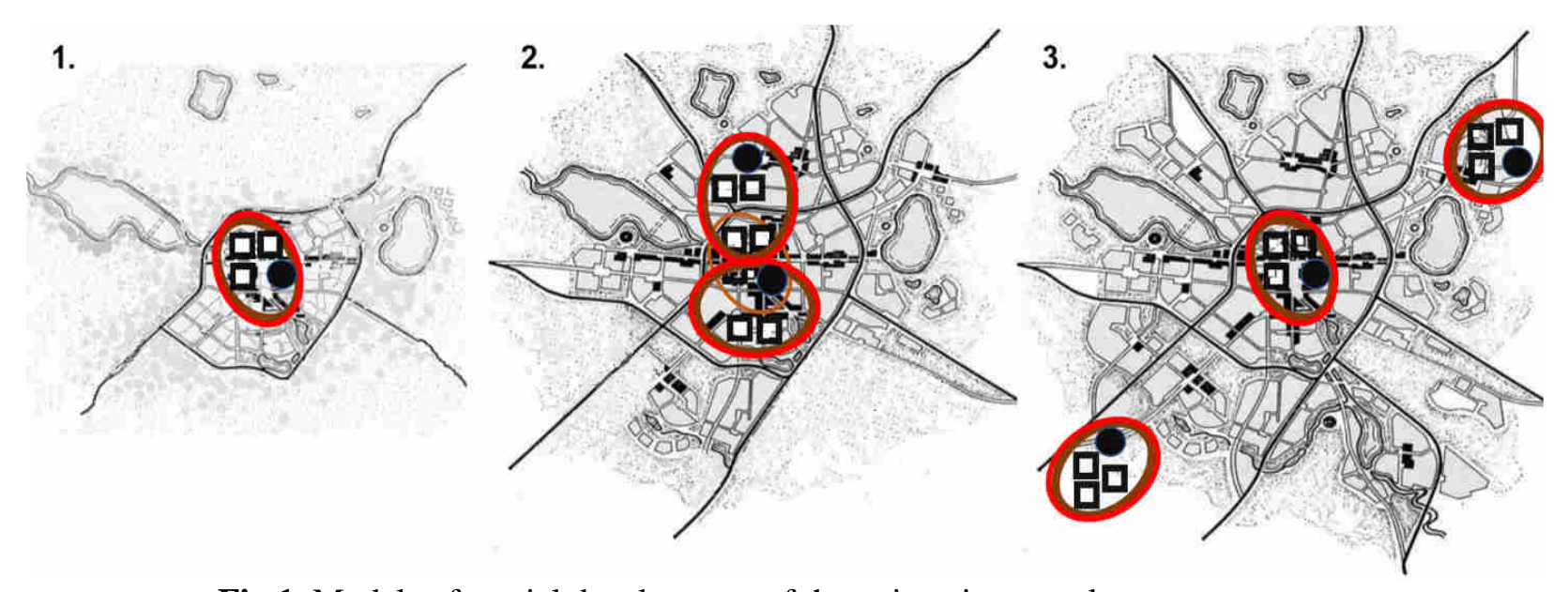

Fig.1. Models of spatial development of the university complex:

1) monocentric; 2) polycentric; 3) dispersed

The primary spatial model of such a city was monocentric, where university was the dominant integral planning element of the urban structure (see Fig.1, Scheme 1). In the following stages, the evolution of the monocentric model of the university complex location in the city planning structure could evolve in several ways.

1) Development of a monocentric model. The dominance of the university complex monocentric location with the subsequent territorial expansion of university separate structural units in the spatial structure of the city. Examples of such monocentric university cities, both at the primary and modern stages are Cambridge, Oxford and St. Andrews.

2) The evolution of the monocentric model into a modern polycentric one is typical for universities, which during their history split into two or more units. For example, the first medical university in France (Montpelier), founded in 1289 by Pope Nicholas IV, is now divided into three autonomous universities. The University of Bordeaux (France), founded in 1441, in 1968 was divided into four independent universities.

After division, these re-created universities are further developed as independent integral planning entities with their own infrastructure (see Fig.1, Scheme 2).

The third model - dispersed - can become an evolutionary continuation of both the monocentric and polycentric models of the university spatial organization. This model is characterized by the creation of new separately standing university structural elements mainly in the peripheral zone of the city (see Fig.1, Scheme 3). Such a model at the present stage is the most common due to the lack of large free areas around the historical city centre, where the primary core of the university is usually located. For example, in Kyiv, this is Taras Shevchenko National University of Kyiv, founded in 1833, separate faculties of which (Faculty of Geography, Faculty of Computer Science and Cybernetics, Faculty of Sociology and Faculty of Mechanics and Mathematics, etc.) are located at a considerable distance from the initial core - the Red Building. The models of the university cities spatial organization are most clearly revealed for cities that have preserved their scientific and educational function as dominant in the overall balance of economic activity.

As already mentioned, a characteristic feature of university cities is a high-students and teachers rate towards the total population of the city. Let's look at this aspect on the example of the most typical university cities (see Table 1).

Depending on the population rate, university cities can be small, medium and big [11]. The bigger is the city (in terms of population), the greater is the city functions diversity [19, 20]. Therefore, cities with a population over 500 thousand people are multifunctional, even despite the big number of educational institutions of higher and secondary level. 
Table 1. Comparative characteristics of the oldest European and innovative university cities (examples)

\begin{tabular}{|c|c|c|c|c|c|c|c|}
\hline \multirow[b]{2}{*}{ No } & \multicolumn{3}{|c|}{ City } & \multicolumn{3}{|c|}{ University } & \\
\hline & State, city & $\begin{array}{c}\text { Year of } \\
\text { establish- } \\
\text { ment }\end{array}$ & $\begin{array}{c}\text { Population, } \\
\text { (thousand } \\
\text { people) }\end{array}$ & University nam & $\begin{array}{c}\text { Year of } \\
\text { estab- } \\
\text { lishment }\end{array}$ & $\begin{array}{c}\text { Population, } \\
\text { thousand } \\
\text { (Residents } \\
\text { +students) }\end{array}$ & \\
\hline 1 & 2 & 3 & 4 & 5 & 6 & 7 & 8 \\
\hline \multicolumn{8}{|c|}{ The oldest European university cities (examples) } \\
\hline 1. & $\begin{array}{l}\text { United Kingdom, } \\
\text { England, } \\
\text { Oxford }\end{array}$ & $8^{\text {th }}$ century & 154,6 & $\begin{array}{l}\text { University of } \\
\text { Oxford }\end{array}$ & 1117 & $\begin{array}{l}26,1 \\
(22,0+4,1)\end{array}$ & $16,9 \%$ \\
\hline 2. & $\begin{array}{l}\text { United Kingdom, } \\
\text { England, } \\
\text { Cambridge }\end{array}$ & $1^{\text {th }}$ century & 124,8 & $\begin{array}{l}\text { University of } \\
\text { Cambridge }\end{array}$ & 1209 & $\begin{array}{l}34,8 \\
(11,5+23,3)\end{array}$ & $28,0 \%$ \\
\hline 3. & $\begin{array}{l}\text { United Kingdom, } \\
\text { Scotland, } \\
\text { St Andrews }\end{array}$ & $9^{\text {th }}$ century & 16,8 & $\begin{array}{l}\text { University of } \\
\text { St Andrews }\end{array}$ & 1412 & $\begin{array}{l}11,7 \\
(2,7+8,98)\end{array}$ & $69,5 \%$ \\
\hline 4. & $\begin{array}{l}\text { Italy, } \\
\text { Bologna }\end{array}$ & 534 B.C. & 392,7 & $\begin{array}{l}\text { University of } \\
\text { Bologna. }\end{array}$ & 1088 & $\begin{array}{l}89,5 \\
(2,9+86,6)\end{array}$ & $22,8 \%$ \\
\hline 5. & $\begin{array}{l}\text { Italy, } \\
\text { Padua }\end{array}$ & $\begin{array}{l}12^{\text {th }} \text { centu- } \\
\text { ry B.C. }\end{array}$ & 214,1 & $\begin{array}{l}\text { University of } \\
\text { Padua }\end{array}$ & 1222 & $\begin{array}{l}61,5 \\
(2,2+59,3)\end{array}$ & 29,1 \\
\hline 6. & $\begin{array}{l}\text { Germany, } \\
\text { Heidelberg }\end{array}$ & 1196 & 160,4 & $\begin{array}{l}\text { Heidelberg } \\
\text { University }\end{array}$ & 1386 & $\begin{array}{l}38,1 \\
(8,4+29,7)\end{array}$ & 23,7 \\
\hline 7. & $\begin{array}{l}\text { France, } \\
\text { Montpellier }\end{array}$ & $\begin{array}{l}10^{\text {th }} \text { centu- } \\
\text { ry }\end{array}$ & 285,1 & $\begin{array}{l}\text { University of } \\
\text { Montpellier }\end{array}$ & 1289 & $\begin{array}{l}44,6 \\
(1,9+42,7)\end{array}$ & $23,4 \%$ \\
\hline 8. & $\begin{array}{l}\text { Netherlands, } \\
\text { Leiden }\end{array}$ & $\begin{array}{l}13^{\text {th }} \text { centu- } \\
\text { ry }\end{array}$ & 124,9 & $\begin{array}{l}\text { Leiden } \\
\text { University }\end{array}$ & 1575 & $\begin{array}{l}37,6 \\
(8,1+29,5)\end{array}$ & $30,1 \%$ \\
\hline 9. & $\begin{array}{l}\text { Spain, } \\
\text { Salamanca }\end{array}$ & $\begin{array}{l}12^{\text {th }} \text { centu- } \\
\text { ry B.C. }\end{array}$ & 144,0 & $\begin{array}{l}\text { University of } \\
\text { Salamanca }\end{array}$ & 1254 & $\begin{array}{l}33,8 \\
(3,6+30,2)\end{array}$ & $\begin{array}{l}23,5 \\
\%\end{array}$ \\
\hline 10. & $\begin{array}{l}\text { Hungary, } \\
\text { Pecs }\end{array}$ & $\begin{array}{l}2^{\text {nd }} \text { century } \\
\text { B.C. }\end{array}$ & 143,3 & $\begin{array}{l}\text { University of } \\
\text { Pecs }\end{array}$ & 1367 & $\begin{array}{l}21,9 \\
(1,9+20,0)\end{array}$ & $\begin{array}{l}15,3 \\
\%\end{array}$ \\
\hline 11. & $\begin{array}{l}\text { Sweden, } \\
\text { Uppsala }\end{array}$ & & 168,1 & $\begin{array}{l}\text { Uppsala } \\
\text { University }\end{array}$ & 1477 & $\begin{array}{l}49,7 \\
(7,1+42,6)\end{array}$ & $\begin{array}{l}29,5 \\
\%\end{array}$ \\
\hline 12. & $\begin{array}{l}\text { Ukraine, } \\
\text { Kyiv }\end{array}$ & $7^{\text {th }}$ century & 15,0 & $\begin{array}{l}\text { Kyiv-Mohyla } \\
\text { Academy }\end{array}$ & 1615 & $\begin{array}{l}1,1 \text { (Year } \\
\text { of } 1700)\end{array}$ & $7,3 \%$ \\
\hline \multicolumn{8}{|c|}{ Contemporary innovative university cities (examples) } \\
\hline 13. & $\begin{array}{l}\text { United Arab Emir- } \\
\text { ates, Masdar }\end{array}$ & 2006 & $\begin{array}{l}40,0 \\
(\exp .)\end{array}$ & $\begin{array}{l}\text { Masdar Institute } \\
\text { of Science and } \\
\text { Technology }\end{array}$ & 2017 & $\begin{array}{l}5,5 \\
(0,5+5,0)\end{array}$ & $\begin{array}{l}13,8 \\
\%\end{array}$ \\
\hline 14. & $\begin{array}{l}\text { Russia, } \\
\text { Innopolis }\end{array}$ & 2014 & $\begin{array}{l}155,0 \\
(\text { exp.) } \\
4,0 \\
(2020)\end{array}$ & $\begin{array}{l}\text { Innopolis } \\
\text { University }\end{array}$ & 2015 & $\begin{array}{l}25,0 \text { (exp.) } \\
700 \text { (2019) }\end{array}$ & $16,1 \%$ \\
\hline 15. & $\begin{array}{l}\text { Ukraine, } \\
\text { Innovation park } \\
\text { UNIT.City (Kyiv) }\end{array}$ & 2017 & $\begin{array}{l}14,0 \\
(\exp .)\end{array}$ & UNIT Factory & 2017 & $\begin{array}{l}3000 \text { (exp.) } \\
900(2019)\end{array}$ & $21,4 \%$ \\
\hline
\end{tabular}


For university cities, the teachers and students share ranges from 15\% (Pecs, Hungary; Oxford, United Kingdom) to almost $70 \%$ (St Andrews, Scotland, United Kingdom). To compare, in Kyiv, the Kyiv-Mohyla Academy, the first officially recognized East Slavic world higher education institution, founded in 1615 , there were around 1,100 students and teachers (in 1700 ) $-7 \%$ of the Kyiv population then. [21]. The average rate value of teachers and students makes $21.7 \%$ of the total city population (see Table 1).

The quantitative parameters, given in Table 1, were obtained from the websites of those cities and universities. These data are not completely accurate, but it should be noted that these figures do not take into account the additional number of support staff and employees of other related departments and facilities involved in university functioning. University plays a powerful city-forming object role, which ensures the whole city existence, creating employment places for numerous service facilities (trade and entertainment facilities, cafes, restaurants, hotels, health care facilities, etc.). University financing is a separate issue. On the one hand, there are budget subsidies for the educational institution's operation. On the other hand, paid educational services, research results commercial effect, numerous start-up companies, as well as the operation of numerous service facilities contribute to local and state budget revenues.

\section{3) Functional planning model of the in- novative city territory}

Functional planning organization of the city at each historical development stage has its own features [7, 20]. The idea of living environment comfort was incarnated in various models of the ideal city - "The Sun City", "The Star City" (rational representation of the city organization as a fortress or shopping center); the "Utopia" city (personification of the society social justice idea); Howard's "Garden City" (the desire to get closer to the natural environment); "Sustainable City" (attempts to solve the problems of economy, society and nature balanced development); "Smart City"
(IT-technologies maximal implementation in everyday life) and finally "Innovative City" (city of science) [20].

The planning organization of cities formed during the period of industrial development is based on the Athens Charter principles [22], they are characterized by the predominating monofunctional territory zoning (residential, industrial and recreational zones), having a well-defined spatial organization. The city central and peripheral parts mainly consist of residential and recreational zone elements with the public service centre forming.

The city peripheral zone consists of the territories of industrial objects, communal warehousing, engineering, transport facilities. A typical model of the industrial city functional planning organization (on the example of the city of Vyshneve, Kyiv region) is shown in Fig.2, Scheme 1.

The innovative city of the modern period is formed on fundamentally different principles. The central and peripheral areas consist of research facilities, innovation centres, higher education institutions, primarily universities and business centres. The middle zone is formed by residential small and medium storey building blocks with the approach to the peripheral recreational zone. The model of functional planning organization of the innovative city is shown in Fig.2, Scheme 2, 3.

The world experience of creating the newest innovative cities with the university, as a core, is actively developing. One of the most vivid examples of an innovative city in the world is the city of Masdar (UAE). It is also called the "City of the Future" or Eco city. It is the first city in the world to be supplied exclusively with solar energy and other renewable energy sources [23]. A sustainable ecological environment with minimal carbon dioxide emissions into the atmosphere, as well as a system of municipal activity complete waste recycling is created in Masdar City [24].

The functional planning organization of this city, where the university with its numerous innovative research centres is in the middle, is presented in Fig.2, Scheme 3. Masdar City construction began in 2006 in the United Arab Emirates on an area of 600 hectares. It is de- 
signed for 50 thousand permanent residents, and as many people as planned will come to work. The project contains the most revolutionary cities organization ideas. Masdar City main idea is "green" technology. Public transportation is located exclusively underground, gasoline engine cars are prohibited. Instead, automatic individual electric transport is pro- vided.

Geothermal and solar energy (solar panels, mirror devices that concentrate sunlight etc.), as well as waste recycling energy, provide the city's energy independence.

Masdar City architecture was designed by prominent architect Norman Foster and it was adapted to the UAE climate.

\section{MASTER PLAN OF VYSHNEVE. UKRAINE - INDUSTRIAL CITY.}



2. MASTER PLAN OF MASDAR-CITY. UAE - INNOVATIVE CITY

Modal of functionalplanning organization of Innovative clty
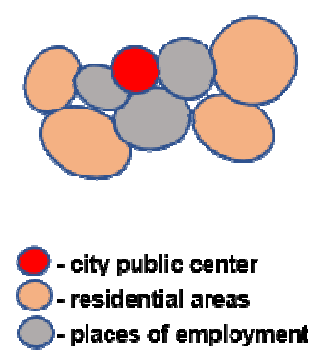

Model of functionalplanning organization of Industrlal city

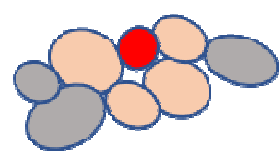

- city public center
- residential areas
- industrial areas
(places of employment)



\section{MASTER PLAN OF UNIT-CITY. UKRAINE - INNOVATIVE CITY}
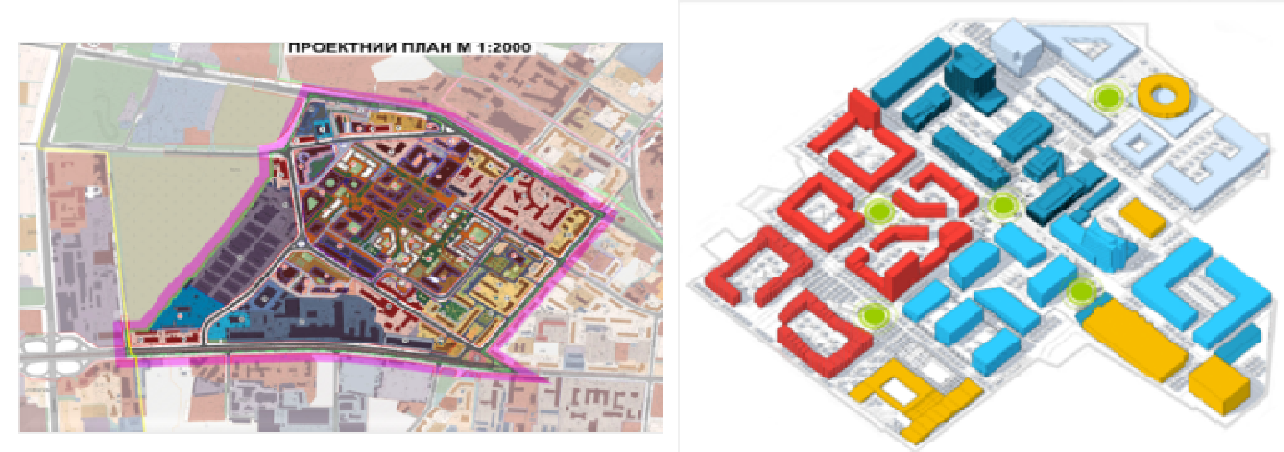

Fig.2. Models of the city territory functional planning organization: Industrial city. Vysneve; 2) Innovative city. Masdar; 3) Innovative city. UNIT.City 
The Innovative City Project has aroused great interest in the world; it has attracted as partners many large corporations that consider Masdar City an experimental and advertising platform. A specialized science campus has already been opened, a solar power plant has been built, well-known companies' and educational institutions' laboratories will soon be opened, including the Masdar Institute of Science and Technology, affiliated with the Massachusetts University of Technology. The expected number of students is 5.0 thousand.

In Ukraine, the experience of new university cities creation is only shaping. The first is UNIT.City in Kyiv. UNIT.City is an example of a multifunctional innovation city with a developed infrastructure. It is being built on the territory of a former industrial enterprise Kyiv Motorcycle Plant/

The site area is 25 hectares, located in the central part of the capital of Ukraine. The land is privately owned, the project is completely commercial.

UNIT.City is positioned as a city within a city, designed for the development of Ukraine's creative economy: conducting innovative business and supporting start-ups, high technologies training, conferences and research, as well as for living, recreation, sports, cultural entertainment [25].

The project provides the creation of up to 15 thousand jobs, construction up to 200 thousand square meters of housing with infrastructure, cultural and educational facilities. Promising number of inhabitants - 14.0 thousand people. The total complex area should be almost 500 thousand square meters, although it may be adjusted depending on demand.

The project is funded privately. It is assumed that the investment amount by 2025 will be $\$ 700-800$ thousand. The partners are the Kyiv-Mohyla Business School and a number of organizations involved in the high technology's development in Ukraine.

The UNIT.City opened in 2017 and is under development now. UNIT.Factory was the first facility to open, which uses an innovative Peer-to-Peer (P2P) training method. It is based on collective learning, which helps to reveal the students' creative abilities while working on projects. The system is based on gamification. The program aims to form high quality software development skills. UNIT.Factory prepares students to work in the most demanding advanced IT companies [26]. Currently almost 800 students study here. In the future the number of UNIT.Factory students will reach 3.0 thousand, of the expected number of 14.0 thousand residents; it will be $21 \%$, which corresponds to the average value rate for university cities.

There are business campuses, Chasopys.UNIT coworking, laboratories, conference halls, recreation areas and sports complex. Newly built UNIT.City facilities are immediately rented out and put into operation.

The UNIT.City is known as a convenient venue for various events. A hundred resident companies, mostly small, already work here. The authors of the project have ambitious plans to make UNIT. City one of the biggest innovations centres in Central and Eastern Europe.

\section{CONCLUSIONS AND RECOMMENDATIONS}

Throughout the human history, the new knowledge - from extracting fire ability to nanotechnology and genetic engineering played an important driving force in the creative habits of individuals and the formation of a comfortable environment for their existence. The material personification of human strives to education and science can be the university as the core of the city spatial planning organization formation.

The university city, known since the Middle Ages, now is acquiring extremely important features not only as a place of education, but also as a basis for building of the new third millennium man. Active implementation of advanced IT-technologies in all activity areas, production and even everyday life requires a high level of education for everyone.

The university as the core of the city plan functional planning organization determines the evolution of the city spatial development. Typical models of such development are monocentric, polycentric and dispersed. 
The activities of the modern university have become more diverse than the primary universities. They are:

- training of future specialists in various fields of activity,

- science and technology development on the basis of research and experimental laboratories and centres, training of scientists;

- commercial educational services to all people, regardless of age and education level;

- creation of public spaces and communication platforms not only for students, but also for all city residents;

- participation in the world globalization process through the introduction of the teachers' and students' educational mobility.

Except for these basic functions, the university creates numerous (up to 20-25\%) employment places. Taking into account the university related areas of activity (cultural and entertainment services, health care, sports and travelling), the number of employees reaches $70-80 \%$ of the working force.

Despite the existence of powerful higher educational institutions in Ukraine with a long history, the classical European type of university cities is not determinative. However, the country has a unique opportunity to create new university cities on the principles of contemporary innovative cities. In particular, this approach can be used to address the problem of rebuilding or reconstructing cities destroyed during the war in the east of the country. To ensure the possibility of implementing such an approach, it is necessary to significantly change the legislative and regulatory framework for urban planning in terms of basic approaches to the formation of functional and spatial organization of the territory of both new and reconstructed cities.

\section{REFERENCES}

1. Avdokushin E.F., 2001. "New Economy": Essence and Structure. Economic theory on the threshold of the 21 st century. 5 Neo-economics, Moskow, Yury`st, 624.

2. Grigoryan A.L., 2005. On the Way to the "New Economy": the Concept of Innovative
Development of Russia. State and society, Moscow, 82-85.

3. Lukyanov A.M., Pleshkanovska A.M., 2017. Intellectual city - standard of future or innovative development of urban areas. Mistobuduvannya ta terytorialne planuvannya, No $65,336-341$.

4. Urban O., 2017. The Value of the City in the Process of Human Self-identification. News of Lviv University, Seriya filosofsko-politologichni studies, Vol. 9, 12-17.

5. Pleshkanovskaya A.,M. 2019. Smart Urban Space for Innovative Education. Smart Education in Smart Society: Possible Ways of Adaptation, Kharkiv, 154-168.

6. Bezgodov D.N., Belyaeva O.I., 2016. Sociocultural Mission of the University in the Region Development. Higher education in Russia, Vol. 6, 128-134.

7. Pleshkanovska A.M., Savchenko O.D., 2019. Epochs and cities. Logos, 264.

8. Ruban L., 2016. Underwater urban studies: modern issues and trends. Underwater Technologies, No 03, 54-55.

9. Perfilieva O.V., 2011. University and Region: on the Way to the Implementation of the Third Function. Bulletin of international organizations No 1 (32), 133-144.

10. Shcherbinin A.I., Shcherbinina N.G., 2012. Before posing the problem of external positioning of a university city. West Tom. state un-ty. No 359, 53-58.

11. DBN B.2.2-12:2019, 2019. Planning and development of territories. Kyiv, Ministry of Regional Development of Ukraine, 177.

12. Sultanova L., 2016. University as a Leading Social Institution in the History of the Development of the University Education. Mountain School of the Ukrainian Carpathians, Vol.14, 79-83.

13. Besov L.M., 1998. History of science and technology from ancient times to the end of the XX century. Kharkov, KhGPI, 168.

14. Gorbach N.Ya., et al., 1992. Theory and history of world and domestic culture. Lviv, Kamenyar, 168.

15. Kozlova Y.V., 2014. Construction of European universities. Historical overview. Urban planning and spatial planning, No 51, 209-219.

16. Zager P., 2012. Oxford and Cambridge. Imperishable history. Moskow, From Olga Morozova, 630 .

17. Rud N., Marchuk O., 2017. Theoretical Foundation for the Formation of Innovative Clusters. 
Law, Economy and Management in Modern Ambience, Belgrade, Serbia, Vol.02, 325-331.

18. Ginzburg L., 1970, Lyrics of the Vagantas (in Lev Ginzburg per.). Moscow, 192.

19. Rudenko L.G., Savchuk I.G., .2014. Classification of International Functions of Cities and their Manifestation in Ukraine. Ukrainian Geographical Journal. No 4, 38-45.

20. Pleshkanovska A., 2019. City Master Plan: Forecasting Methodology Problems (on the example of the Master Plans of Kyiv). Transfer of Innovative Technologies, Vol.2, No 1, 39-50.

21. Rudakova J., 2015. To the 400th anniversary of the Kyiv-Mohyla Academy: events, names. Vernadsky National Library of Ukraine, Received

from:

http://www.nbuv.gov.ua/node/2573

22. Le Corbusier, 1976. Three forms of settlement. Athens Charter. Per from the French. J. Rosenbaum. Moskow, Stroyizdat, 136.

23. Goldenberg S., 2016. Masdar's zero-carbon dream could become world's first green ghost town. Received from:

https://www.theguardian.com/environment/201 6/feb/16/masdars-zero-carbon-dream-couldbecome-worlds-first-green-ghost-town.

24. Lawton M., 2009. Renewable energy agency to call United Arab Emirates home, Deutsche Welle (June 29, 2009). Received from: https://www.dw.com/en/renewable-energyagency-to-call-united-arab-emirates-home/a4442082.

25. UNIT.City, The first Ukrainian innovation park. Received from: https://unit.city/en/home/.

26. UNIT Factory, 2017. Project with UFutureInvestment Group support. Received from: https://unit.ua/uk/.

\section{Университет как ядро функционально- планировочной организации инновационного города}

\section{Алла Плешкановская}

Аннотация. Скачкообразное распространение IT-технологий на современном этапе неоекономического развития человечества, формирования разумных и инновационных городов демонстрирует чрезвычайный рост значимости науки и образования. Как следствие, ядром пространственной организации современного города все чаще начинают выступать университеты, научно-исследовательские центры и высокотехнологичные производства.
В статье рассмотрены этапы исторического развития университетов как фокусов концентрации научной мысли и технологических знаний общества - античный (формирование и развитие философской мысли), средневековый (становления университетов и формирования научных направлений - гуманитарного или тривиум, и точного или квадриум), новейший (распространение точных наук как базиса технико-технологических новаций и развития промышленного производства).

Охарактеризованы модели пространственного развития университетов как неотъемлемой составляющей функционально-планировочной организации города, преобладающей функцией которого выступает образовательная или научно-технологическая функция. Это - моноцентрическая (университет доминирует как целостный планировочный элемент в структуре города); полицентрическая (формирование группы университетов как самостоятельных планировочных образований на базе единого исторически сложившегося университета) и рассредоточенная (пространственное развитие моно- или полицентрической модели с сформированием отдельно расположенных структурных элементов университета, преимущественно в периферийной зоне города).

Приведены актуальные количественные показатели отдельных, наиболее характерных, зарубежных и отечественных городовуниверситетов, в частности, доля численности профессорско-преподавательского состава и студентов университета в общем количестве населения университетского города.

Охарактеризованы функции университета на современном этапе развития общества - образовательная, научно-исследовательская, просветительская, коммерческая, коммуникационная.

В статье изложены тенденции трансформации функционально-планировочной организации современного города. Охарактеризованы примеры пространственной организации инновационных городов на примере города Масдар (ОАЭ) и UNIT-City (Украина). Даны рекомендации по возможной трансформации существующих отечественных городов по модели инновационного города-университета.

Ключевые слова: университет, университетский город, инновационный город, пространственная организация, функциональнопланировочная организация, функции университета. 